\title{
The Problems Encountered by Navigation Cadets at Sea Training Phase as a Part of Their Academic Programme
}

\author{
Ergun Demirel \\ Maritime Faculty, Piri Reis University, Istanbul, Turkey \\ Email address: \\ ergundemirel@yahoo.com

\section{To cite this article:} \\ Ergun Demirel. The Problems Encountered by Navigation Cadets at Sea Training Phase as a Part of Their Academic Programme. Teacher \\ Education and Curriculum Studies. Vol. 5, No. 2, 2020, pp. 22-29. doi: 10.11648/j.tecs.20200502.12
}

Received: July 22, 2019; Accepted: August 28, 2019; Published: May 18, 2020

\begin{abstract}
Vocational education for seafaring officers is a long process. During this period, the educational programs proceed within a periodical improvement framework. Sea Training is an integral part of Maritime Education and Education (MET) and it is a part of academic program in the MET institutions. All seafaring officers should complete at least one year Sea training on board the ships to finalize their education. This training should be completed suitable commercial vessels and specially designed training ships. Initial evaluation of sea training are made by the ships which the cadet attended and the maritime schools made the final assessment to verify their achievement at sea training. Practical training is an absolute must for every type of seafarer's education. The aim is to consolidate the academic knowledge taught and practical experience gained at sea. So, on the practical side of the curriculum, sea training comes into prominence during maritime education and that is what we discuss in this study. The main purpose of this research is to pinpoint the main problems encountered by cadets during their sea training phase, and make some suggestions for possible solutions to ensure quality and efficiency of the training. The study starts with a group study base on field study, to define the hypothesis is for questions of questionnaire for cadets participated sea training. The evaluation of the responds are used to finding and subsequently results and proposals. In addition, it is strongly suggested that the collected data and provided findings in this project are taken forward for further studies on this subject.
\end{abstract}

Keywords: Sea Training, Practical Training, Maritime Education and Training, Education of Cadets

\section{Introduction}

Practical training is an absolute must for every type of seafarer's education. The aim is to consolidate the academic knowledge taught and practical experience gained at sea. So, on the practical side of the curriculum, sea training comes into prominence during maritime education and that is what we discuss in this study.

Vocational education for seafaring officers is a long process. During this period, the educational programs proceed within a periodical improvement framework. Sea Training is an integral part of Maritime Education and Education (MET) and it is a part of academic program in the MET institutions. All seafaring officers should complete at least one year duration of sea training on board the ships to finalize their education. This training should be completed suitable commercial vessels and specially designed training ships. Initial evaluation of sea training are made by the ships which the cadet attended and the maritime schools made the final assessment to verify their achievement at sea training.

It should normally be conducted in two parts; while First Phase is for becoming an able seaman, Last Phase is for navigational engineers to practice their vocational knowledge and abilities. Academic education and sea training may overlap. As the very essential vocational knowledge is provided in the last period of academic education program at collage, the most difficult challenge is to match sea training phases and academic education program.

The main purpose of this research is to identify the main problems encountered by cadets during their sea training phase, and make some suggestions for possible solutions.

The common findings on the main problems encountered by cadets during sea training are identified in the previous researches are as follows; Overload and unbalanced working on board, Not having enough options to arrange a more suitable ship for sea training, Not having enough maritime 
knowledge provided by schools before going to sea training, Difficulties met in completing the training portfolio, Insufficient oral English skills, Need for a special training ship

When we stress on the importance of the sea training, we should also realize that there are many risks and difficulties in maritime sector. It means that today officers and ratings are expected to have required academic knowledge and practical ability simultaneously. This serious challenge can only be overcome by college type education. Whilst cadets have to familiarize themselves with ship and sea very well. The standard of judgment of a cadet could only improve by knowledge and experience, for example by deciding what to do correctly and fast due to weather conditions that can change any time. This is not possible learning through schemas, drawings and even photos. In this respect, sea training clearly sets forth its importance.

\section{Methodology}

The aim of this research is to pinpoint the main problems encountered by cadets during their sea training phase, and make some suggestions for possible solutions to ensure quality and efficiency of the training.

Initial evaluation of sea training is made by the ships which the cadet attended and the maritime schools made the final assessment to verify their achievement at sea training. The assessment of the schools is actually verification of success of sea training based on the records approved by ship officials and a verbal interview to prove all the facts in portfolio by maritime lecturers.

There is no possibility to reach the results of sea training in order to get more detailed information except the record on the portfolios made by ship master and ship training officers. In order to reach more reliable finding, it is intended to make a survey covering a reasonable number of cadets. The main purpose of this survey is to pinpoint the main problems encountered by cadets during their sea training phase directly from the trainees.

The study starts with a group study base on field study, an expert group study to define some visible facts and the hypothesis is for questions of questionnaire for cadets participated sea training. The findings of expert groups and evaluation of the responds are used to define finding and subsequently results and proposals to ensure quality and efficiency of the training

The collected data and provided findings in this study may be taken into account for further studies on Maritime education and training (MET).

\section{Research}

\subsection{Field Study}

\subsubsection{The Basis of Maritime Education and Training}

The International Maritime Organization (IMO)'s international convention on Standards of Training,
Certification and Watch-keeping for seafarers (STCW78/2010) [1] ratified by all maritime nations, regulates the principals and standards of Maritime Education and Training (MET). The education and training programmes which meet the requirement in the STCW have been clearly defined by IMO Model Courses. IMO Model Courses 7.01 [2], 7.02 [3], 7.03 [4] and 7.04 [5] covers all details of operational and managerial level deck and marine engineering education. In line with these model courses, ISF (International Shipping Federation), representing maritime industry, has published structured Sea Training programmes. The ISF recommended programmes have been accepted as a base line and approximately all maritime administrations submitted their sea training requirements with very small modifications.

The inherent needs of modern navigation require the MET to provide both education and training. Education means to give students or trainees the theoretical knowledge by means of lecturing and instructing, which could be done on a campus or on board ship. Training means to develop students or trainees' practical skills, which can be accompanied through the organisation of workshops, simulator training, and on board training [6].

New and on-going developments in the shipping industry, year-to-year place increased compliance requirements on MET institutions and in turn additional demands on the students who must carry out their applications in practical settings [7].

Nowadays on the job training become rather important to improve the practical knowledge and the skills of the students in particular for the jobs directly related to use of the equipment to achieve their mission such as engineering. On the job training will also help the students to get familiarized to their future work places. Understanding this situation the education and training institutes should pay more attention to on-the-job training. That means they should prepare better on the job training guidance and produce procedures to conduct an effective on the job training [8].

\subsubsection{Programme Design Philosophy for Seafaring Officers}

The Navigation Engineering) programmes in the faculties are generally planned in five phases;

1. First Academic Phase is designed to introduce and address the main aspects of Seamanship, Navigation and Navigation Watch including mathematics and science units which provide a foundation for engineering education.

2. First Sea Training Phase is generally conducted to equip them with able seaman skills and 3-4 months.

3. Second Academic Phase covers the mathematics and science courses to enable them to continue with the "Ship Construction, Ship Stability, Cargo Handling and Advance Navigation" courses which knowledge and skills acquired in this phase. The "Second Phase" systematically progresses to fulfil the requirements necessary for taking-on higher level complex responsibilities in Navigation Engineering shipboard activities. 
4. Second Sea Training: It is intended to arm cadets with Officer of the Watch knowledge and skills and is expected to be conducted on board of capable and qualified ships for 7 to 8 months.

5. Third Academic Phase: The advanced maritime studies such as Maritime Economics, Port Operations, Safety Management, Risk Management, and Logistics Management, for future professional progression on the maritime business and academic development are included in are delivered in this phase.

\subsubsection{Sea Training System in Different Countries}

Yoon et al [9] made a study on sea training and education in the training ships of three countries including the United States, Japan, and South Korea based on the STCW requirements. This research found that some difference applications of training and education are performed and conducted in terms of time period of training, training institution, and faculty \& staff arrangement. SWOT analysis will be conducted for the each training and education in the training ship of the countries in terms of most effective cost approach, education method for cadet, and training time and period.

Yoon and Ko [10] introduced a paper at Third Maritime Education Summit - Texas A\&M on "Maritime training and education on-board training ships are compared among the maritime colleges in Asia including China, Japan and South Korea". By comparing the education and training these college offers, this paper shows differences of training and education on-board the training ships, accordingly. Their main proposal focused on the improvement of methods for sea training and essential issues for use of training ships.

In all of the instances where information is available, the national or regional authorities pay for land-based education facilities while shipowners generally pay for on board training. It appears that it is necessary to find a solution to put the government, MET institutions and ship owners to cooperate for better MET to meet the requirements of STCW Convention [1] and the ISM [11] Code into practical education and training.

\subsubsection{The Current Projects on MET}

European Union Seventh Framework Programme (FP7) [12] plays a crucial role in reaching the EU goals of growth, competitiveness and employment. FP7 encourages the cooperation between partners in particular on Transfer of Innovation and best practises in other countries. Although many MET related EU projects is initiated to reach this goal, but unfortunately there is not a project on the improvement of sea training.

\subsubsection{Relation between MET Institution and Shipping Company}

Although there are sufficient land-based training facilities, on-board training places could be increased, for example by exploiting the provisions in the state aid guidelines. Indeed, the increased availability of the supplementary training would increase the employability of the European seafarers. Increased collaboration between the shipowners associations, social partners and public bodies provides better opportunities to match the emerging skills needs with appropriate training supply [13].

From an institute's point of view, the program should be capable of meeting the requirements of the position on board. The institute needs to understand more about shipping companies, ship-operation practice and seamanship, etc. while a shipping company can design training programs according to a trainee's level (knowledge basis and skills mastered) and requirements of the job. In this case, refreshment should be brought into line to avoid unnecessary overlap. So these two organisations are two facets of one thing, in that they should connect and co-operate become competent, and the aim of safer ships and cleaner oceans will be realised [14].

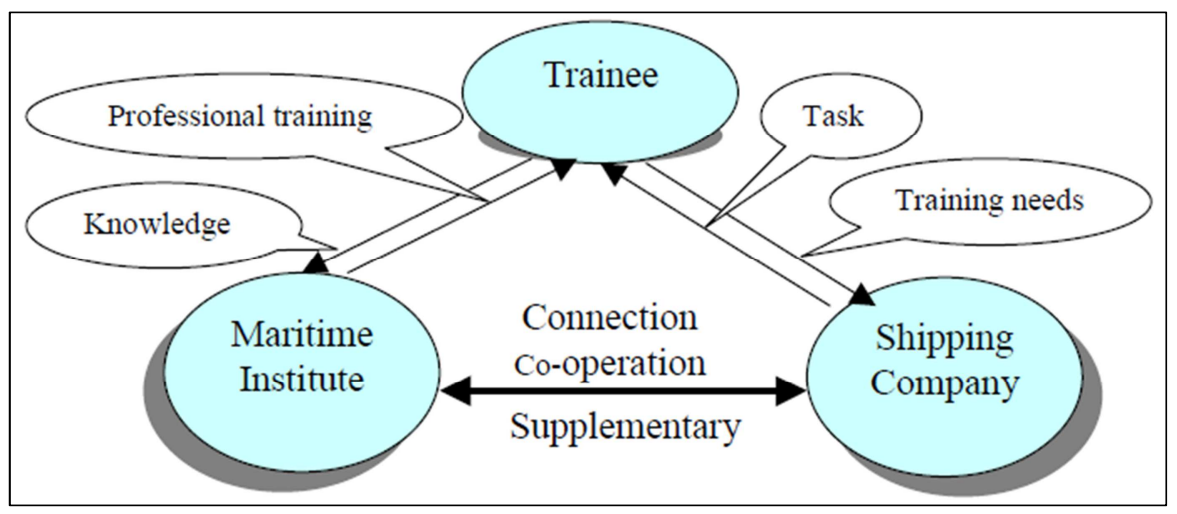

Figure 1. Linkage between a MET Institute and a Company (Source: Shen, 2019).

It is clear that there is not a good cooperation and coordination between MET institutes and shipping companies which both of them are important for the success of the seat training. So these two organisations are two facets of MET, in that they should connect and co-operate become competent to ensure the quality education and training.

\subsection{Group Study}

A group has established by 5 maritime lecturers who are all masters and served as maritime lecturer at least since 10 years. The group members are also doing the verification of 
the end of sea training and making overall academic assessment.

Firstly the group has studied on the completed sea training portfolios. The content of portfolios are in line with $\operatorname{ISF}^{\wedge} \mathrm{s}$ recommended portfolio [15]. Assessment of 86 portfolios are checked by the group members. As far as concerning the evaluation of the portfolio, the average of the Masters' Evaluation is $89.2 / 100$ as the verifiers' assessment grade was $81.4 / 100$. The master's evaluation is found highly optimistic.

The resume of field study is introduced to the group members at the beginning of the group study. The following issues are found as main problem areas during sea training as a result of the previous experience of the participants.

1. Work overload: Some of the cadets are accepted by companies as not only trainees but also rating. These enforce cadets not to make training but also doing responsible crew member jobs.

2. Difficulties in completing the training portfolio: There is not a sufficient support from ship crew to give help the cadets to fill their portfolios.

3. Not having enough background before the training: There are some differences between information delivered in the schools and competencies on board specific ships. It is impossible to provide sufficient knowledge on specific types of the ships. The cadets may be delivered generic knowledge at the schools and cadets may learn specific information types of the ships such as LPG/LNG, chemicals, Ro-Ro etc.

4. The cadets are not having enough options to arrange a more suitable ship for sea training: Some ships such as operating in inner waters or short sea liners are not suitable to meet all requirements of sea training. But due to lack of sufficient number of ships to cover huge number of cadets, some cadets go sea training on board of these under-qualified ships.

5. Insufficient English oral skills: Most of the cadets expresses that all the documents are English but their language skills are not sufficient to follow it. In particular they have had problems in oral skills.

The group has defined 8 hypotheses to be tested and evaluated with a questionnaire. These hypotheses have been provided in the sub-paragraph 3.3 and not to be mentioned here to avoid repetition.

\subsection{Survey Results and Analysis}

The survey is based on the hypotheses defined by expert groups. It is aimed that the survey should cover at least half of total of a number of cohort minimum a cohort. The names of the cadets are asked optional to allow them to express their opinion freely.

\subsubsection{Participants}

The questionnaire covers 24 questions supporting 9 hypotheses. The 69 cadets at the final year were participated. This is approximately $\% 76$ percent of total final year students (103) and number of the participant of survey is sufficient and reliable for evaluation. The gender is not important for the hypothesis of survey and is not counted.

\subsubsection{Type of the Ship Where the Students Have Sea Training}

The distribution is shown as percentage:

Container: 17\% Bulk Carrier: 29\% Tanker: 36\% LPGLNG: 0\% Ro-Ro: 7\% Cruise Ship: \% 0 Other types: 11\%

The students who are also sailed on Training ship: \%11

Taking into account ship types of Turkish-owned fleet (Container: 16\%, Bulk Carrier: 35\% Tanker: 29\% Ro-Ro: 7\% LPG-LNG: $3 \%$ Other types: $10 \%$. Distribution of students on board the ships it is in line with the composition of the fleet.

\subsubsection{Duration at Sea Training}

Between 1-6 months: 50\% Between 6-8 months: 35\% between $8-12$ months: $15 \%$

$50 \%$ percent of the cadets stayed at sea between 6 to 12 months and at least half of the cadet are fully eligible to make an assessment.

Nationality of Crew On-board?

All Turkish: 69\% All non-Turkish: 0\% Mostly Turkish: 15\% Mostly non-Turkish: $16 \%$

That shows $69 \%$ has not experienced language and cultural problems. None of the cadets served (Mostly Turkish: 15\% Mostly non-Turkish: 16\%) reported language and cultural problems in the following parts of survey.

\subsubsection{Hypothesis}

H1: Finding a training ship is not easy.

How did you manage to find a ship to go sea training?

By your own efforts: 51\% With assistance of school 18\% With help of a friend: $6 \%$

With help from your family: $22 \%$ With help from a society: 3\% Other: $0 \%$

Half of the students find a training ship by own efforts that means they are able to find ship by their own efforts. $22 \%$ find ships with help from your family because mostly a quarter of the cadets are coming from maritime industry. The assistance of school is low (18\%).

H1 is proved.

$\mathrm{H} 2$ : School does not provide sufficient background before how to complete the portfolio before sea training

Did your school inform you adequately understand how to complete the portfolio before sea training?

Yes: $31 \%$ No: $22 \%$ Not adequately: $47 \%$

$69 \%$ of the cadets expressed that school does not provide sufficient information about preparation of portfolios. This subject should be considered.

H2 is proved.

H3: The deployment of cadets in different post during sea training is reasonable.

How do you rate your tasking during sea training?

a) Bridge Watch: $44 \%$ b) Maintenance: $38 \%$ c) Study: $18 \%$

d) Other: $0 \%$

Tasking of cadets is reasonable taking into account ship routine.

How drills been carried out on your ship?

Yes, periodically: 56\% Yes, generally: $25 \%$ Yes, partly: 13\% Not conducted: $6 \%$ 
Drills are conducted generally or periodically except a few ships which are reluctant.

Please specify your role when attending anchoring and mooring operations?

$\begin{array}{llll} & \begin{array}{l}\text { Always } \\ (\%)\end{array} & \begin{array}{l}\text { Sometimes } \\ (5)\end{array} & \begin{array}{l}\text { Never } \\ (\%)\end{array} \\ \text { As helmsman } & 16 & 64 & 20 \\ \text { On Forecastle deck } & 17 & 71 & 12 \\ \text { On Poop deck } & 14 & 75 & 11 \\ \text { As Junior OOW } & 17 & 60 & 23\end{array}$

Anchorage and mooring are distinctive operations on board. If the student attendance in critical positions during these operation is evaluated, it is understood that ships are deployed the students in a reasonable form.

H3 is proved.

H4: The major problems encountered are not to get trained properly and too much work on board.

Assessment of the biggest problems which anchoring and mooring operations a cadet faces when on sea training?

Insufficient pocket money: 15\% Not enough opportunity to get trained properly: $\% 37$

Personal problems (not being able to get along well with the others): $3 \%$

Not being able to complete sea training portfolio properly: 3 Accommodation Problems: 3\%

Health problems: $1 \%$ Too much work to do: $29 \%$ Other (Specify): 6\%

$63 \%$ of the cadets believe they get proper training. $29 \%$ of cadets believe that they have much work to do. Actually there are some ships which are not suitable for sea training in particular ships sailing near distance such as Black Sea and Marmara Sea lines. Some of the cadets are accepting to work as a rating with a little payment or companies accept the cadet on boards if they accept to work as a rating. This is the real reason which creates access work load and reduce the effectiveness of training.

H4 is proved.

H5: Satisfaction of cadets from sea training is well

How do you rate the benefits you've gained from your sea training?

Very much: 23\% Satisfied: $47 \%$ Average: $25 \%$ Not much satisfied: 9\% Not satisfied: $0 \%$

Most of the cadets are satisfied from sea training.

How do you feel that you are ready to go sea duty after this sea training?

Fully ready: 14\% Ready: 24\% Ready except some respects: $60 \%$ Not fully ready: $2 \%$

Most of the cadets feel that you are ready to go sea duty after this sea training

H5 is proved.

H6: Support of ship officer and crew is not sufficient

From whom did you get the most assistance on your training?

Captain: 8\% Chief Officer: 63\% Chief Engineer: 0\% 2nd/3rd Officer: 23\% Bosun: $\% 2$

The $\mathrm{C} / \mathrm{O}$ contribution is good. $2 \mathrm{nd} / 3 \mathrm{rd}$ Officers also provide sufficient. Master is contribution is law and no participation of Chief Engineer in training. Bosun is important for seamanship training but it is also very low.

How do you rate the captain's behaviour towards you and your studies?

Very satisfied: $12 \%$ Satisfied: $23 \%$ Neither satisfied nor dissatisfied: $61 \%$ Dissatisfied: $4 \%$

How do you describe the captain's behaviour towards you and your studies?

a) He was always helpful and supervised my studies: $30 \%$

b) He was trying to be helpful but did not have enough time: $45 \%$

c) He was impartial to me: $7 \%$

d) He disliked and ignored me: 3\%

e) He had nothing to do with me: $12 \%$

f) He developed a hostile behaviour towards me: $3 \%$

Unfortunately Ship Masters support of sea training is generally very unsatisfied.

How do you rate the overall performance of the ship's officers towards your training?

Very satisfied: 59\% Satisfied: $21 \%$ neither satisfied nor dissatisfied: $20 \%$ Dissatisfied: $0 \%$

General Assessment of the support of crew is good in particular $\mathrm{C} / \mathrm{O}$. But there is a significant issue that ship masters are very reluctant for cadet's sea training.

H6 is partly proved.

H7: Cadets view on sea training is positive

What would you wish? (You may choose more than one option)

a) I wish I had never gone sea training as a cadet: $8 \%$

b) I wish I had given more information about program before sea training: $26 \%$

c) I wish I had studied more and understand more about ships before sea training: $24 \%$

d) I wish I was given more options to find a better ship for sea training: $21 \%$

e) I wish I had studied and practiced more in English: 21\%

50 percent of the students are agree that they should studied more and understand more about ships before sea training as well as they have been given more information about program before sea training:

How important you think the sea training is for your career as a merchant ship officer?

Indispensable: $27 \%$ Very important: $58 \%$ important: $15 \%$ Not necessary: $0 \%$

The cadets believe that sea training is very important for their career.

H7 is proved.

H8: School support of sea training is not sufficient

On what matter might your school have provided more assistance for you? (Choose more than one option)

a) Should have provided more information on Maritime English matters: \%15:

b) Should put more stress on practical shipboard operations: \%15

c) Should have provided more on fundamental courses (physics, mathematics): $4 \%$ 
d) Should have prepared us better before the sea training: $34 \%$

e) Has nothing more to do (satisfactory): $6 \%$

How do you rate your schools' support for you during training ship?

Very satisfied: 3\% Satisfied: 30\% Neither satisfied nor dissatisfied: $40 \%$ Dissatisfied: $18 \%$

How do you rate your English skills when as a cadet onboard?

Very satisfied: $28 \%$ Satisfied: $48 \%$ neither satisfied nor dissatisfied: 49\% Dissatisfied: $0 \%$

It is understood that there are some problems on the schools activities to prepare cadets for sea training as well as students express that they need school's support to find a suitable ship for training.

H8 is proved.

H9: There is a need for training ship

How do you rate the schools' need for its own training ship?

A must: $24 \%$ A necessity: $24 \%$ Nice to have: $45 \%$ Not necessary: $5 \%$ A total waste: $2 \%$

The half of students believe there is a need for training ship as $\mathrm{m}$ believes half of the $\mathrm{n}$ students believes not.

H9 is proved

Overall Assessment

Al these findings are collated and some of them are associated to be discussed in the discussion section. There is not any other specific comment by the cadets.

\section{Discussion}

\subsection{Work Overload}

Some of the cadets are accepted by companies as not only trainees but also rating. These enforce cadets not to make training but also doing responsible crew member jobs. This was an approach to facilitate the finding a training ship for the cadets. But unfortunately it has been misused by some ships. Maritime Administrations should take measures to prevent from this type of misuses.

The students had difficulties in completing the training portfolio in particular the cadets were deployed as ratings. There is not a sufficient support from ship crew to give help the cadets to fill their portfolios.

\subsection{Not Having Enough Background before the Training}

There are some differences between information delivered in the schools and competencies on board specific ships. It is impossible to provide sufficient knowledge on specific types of the ships. The cadets may be delivered generic knowledge at the schools and cadets may learn specific information types of the ships such as LPG/LNG, Ro-Ro etc.

\subsection{The Cadets Are Not Having Enough Options to Arrange a More Suitable Ship for Sea Training}

Some ships such as operating in inner waters or short sea liners are not suitable to meet all requirements of sea training. But due to lack of sufficient number of ships to cover huge number of cadets, some cadets go sea training on board of these under-qualified ships.

Half of the students find a training ship by own efforts that means they are able to find ship by their own efforts. $22 \%$ find ships with help from your family because mostly a quarter of the cadets are coming from maritime industry. The assistance of school is low (18\%).

\subsection{Insufficient English Oral Skills}

Most of the cadets expresses that all the documents are English but their language skills are not sufficient to follow it In particular they have had problems in oral skills. The cadets rating their English skills as a cadet on-board: Very satisfied: $28 \%$, Satisfied: $48 \%$, Neither satisfied nor dissatisfied: $49 \%$, Dissatisfied: $0 \%$. It is understood that there are some problems on English language skills gained at the schools to prepare cadets for sea.

\subsection{The Deployment of Cadets in Different Post/Positions During Sea Training}

Anchorage and mooring are distinctive operations on board. If the student attendance in critical positions during these operation is evaluated, it is understood that ships are deployed the students in a reasonable form. Drills are conducted generally or periodically except a few ships which are reluctant.

\subsection{The Major Problems Encountered by Cadets}

Insufficient pocket money: 15\%, Personal problems (not being able to get along well with the others): $3 \%$, Not being able to complete sea training portfolio properly: 3 Accommodation Problems: 3\%, Health problems: 1\%, Other (Specify): 6\%. As a result of Pareto Analysis Not enough opportunity to get trained properly $(\% 37)$ and "too much work to do $(29 \%)$ are the major problem areas.

\subsection{The Quality of Training and Assessment of Training}

$63 \%$ of the cadets believe they get proper training. $29 \%$ of cadets believe that they have much work to do. Actually there are some ships which are not suitable for sea training. Some of the cadets are accepting to work as a rating with a little payment or companies accept the cadet on boards if they accept to work as a rating. This is the real reason which creates access work load and reduce the effectiveness of training.

Rating benefits gained from your sea training; Very much satisfied: $23 \%$, Satisfied: $47 \%$, Average: $25 \%$, Not much satisfied: $9 \%$, Not satisfied: $0 \%$. Most of the cadets are satisfied from sea training.

Student feelings that they are ready to go sea duty after sea training; Fully ready: $14 \%$, Ready: $24 \%$, Ready except some respects: $60 \%$, Not fully ready: $2 \%$. Most of the cadets feel that you are ready to go sea duty after this sea training

As far as concerning the evaluation of the portfolio, the average of the Masters' Evaluation is $89.2 / 100$ as the verifiers' assessment grade was $81.4 / 100$. The difference is over 10 percent and master's evaluation is found highly 
optimistic. A better master evaluation system should be created to reach a more realistic evaluation.

\subsection{Support of Ship Officer and Crew}

The $\mathrm{C} / \mathrm{O}$ contribution to cadets is good and $2 \mathrm{nd} / 3 \mathrm{rd}$ Officers also sufficient. Master's contribution is law and no participation of Chief Engineer in training. Bosun is important for seamanship training but it is also very low.

The captain's behaviour towards cadets and their studies; $30 \%$ says he helpful and supervised my studies, $45 \%$ says he was trying to be helpful but did not have enough time, $12 \%$ says he had nothing to do with me, $7 \%$ says he was impartial to me.

General Assessment of the support of crew is good in particular Chief Officers. But there is a significant issue that ship masters are very reluctant for cadet sea training.

\subsection{Cadets View on Sea Training and School Support of Sea Training}

50 percent of the students are agree that they should studied more and understand more about ships before sea training as well as they have been given more information about program before sea training:

The students' assessment the importance of sea training is for your career as a merchant ship officer; Indispensable: 27\% Very important: $58 \%$ important: $15 \%$.

The cadets believe that sea training is very important for their career.

On the school support to sea training half of the cadets needs more support from the school on sea training in particular practical shipboard procedures and maritime English.

Additionally establishment of an online Sea Training Support system by the university will be useful to assist the cadets to solve their problem at sea training. On- line Sea Training System of Nautical Faculty of Barcelona. (FNB) could be a good example for this application

The half of students believe there is a need for training ship as $\mathrm{m}$ believes half of the $\mathrm{n}$ students believes not.

MET programmes should be arranged in a way so that students can be given an early exposure to life on board a ship, at least on a training vessel. This would allow MET students to find out whether they made an appropriate choice of career and, if not, would save MET capacity and costs and future disappointment and dissatisfaction for those who dislike shipboard life [16]. A sea experiment on board a training ship at early stages of education will provide an opportunity to cadets to realize the real aspects of sea life.

\subsection{Relation between MET Institutes and Shipping Companies}

More on-board training places should be made available by ship owners/ship operators so that MET students can complete their training for a certificate of competency. This recommendation should be seen in context of possible incentives for those who provide on-board training places and, in a wider context, the provision of incentives for the flagging back of ships to a flag of an EU country [12].

It is clear that there is not a good cooperation and coordination between MET institutes and shipping companies which both of them are important for the success of the seat training. So these two organisations are two facets of one thing, in that they should connect and co-operate become competent on the sae training.

\section{Conclusion}

a. Not having enough background before the training

Although ISF Sea Training Portfolio is prepared in line with IMO Model Course 7.03 there are some differences between information delivered in the schools and competencies require practical application on board. Ship masters/officers has an opinion that school does not provide sufficient information for on-board application as well as the students. It would be suitable to make an additional study to define missing points and reflect this subjects in the MET programme as much as possible.

\section{b. Work overload}

In order to facilitate the acceptance of cadets for sea training some countries allow the companies to accept the cadets also as a rating. But this application is misused by the companies by using the cadets as seaman not cadet. This causes a condense workload for cadets which hampers their effort to achieve duties at the portfolio. Maritime Administrations should take measures to prevent from this type of misuses.

c. Finding a ship more suitable ship for sea training

Due to lack of sufficient number of ships to cover huge number of cadets, some cadets go sea training on board under-qualified ships. The efforts of schools is not sufficient to find suitable ships for cadets. To ensure the quality of sea training Maritime Administration review their regulation to facilitate finding better quality of ships for training.

\section{d. Insufficient English oral skills}

Unfortunately English language skills of cadets are not sufficient to accomplish requirement in the STCW in particular oral skills. The maritime schools should give more emphasis to English language.

e. The deployment of cadets in different post/positions during sea training

Deployment of students at different posts is suitable except a few ships. But it is understood that some ships are not conducted the drills as required which create a negative impact for training

\section{e. The major problems encountered by cadets}

As a result of PARETO analysis two major problem areas reported by the cadets are "too much work to do $(29 \%)$ and "not enough opportunity to get trained properly (\%37)". The possible reason for too much work is deployment of cadets also as rating. Explained in the paragraph $5 \mathrm{~b}$ (Work Overload). This situation also hampers the activities should be done during sea training. It also hampers deployment opportunity as Junior Officer of the Watch duties which requires to be completed during the second phase of sea training

\section{$f$. The quality of training}


Approximately $2 / 3$ of cadets believes that they get proper training. $1 / 3$ of cadets believes that some additional measures should be taken to ensure the quality.

Most of the cadets satisfied from sea training and they are ready to go sea duty after this sea training.

g. Support of ship officer and crew

The support of crew is good in particular Chief Officers. But there is a significant issue that ship masters are very reluctant for cadet sea training. Bosun is important for seamanship training but it is also very low.

h. Cadets view on sea training is positive

50 percent of the cadets are agree that they should studied more and understand more about ships before sea training as well as they have been given more information at the school before sea training. 85 percent of the cadets believe that sea training is very important for their career.

i. School support of sea training is not sufficient

Students express that they need school's support for more information on Maritime English and practical shipboard operation matters. Additionally establishment of an online Sea Training Support system by the school will be useful to assist the cadets to solve their problem at sea training.

\section{$j$. Need for training ship}

The half of students believe there is a need for training ship as $\mathrm{m}$ believes half of the $\mathrm{n}$ students believes not. Although it creates extra cost for MET, availability of a training ship will facilitate the conduct of early stages of sea training and provide a clear idea on life at sea for cadets.

\section{$k$. Assessment of Sea Training}

As far as concerning the evaluation of the portfolio, the average of the Masters' Evaluation is $89.2 / 100$ as the verifiers' assessment grade was $81.4 / 100$. The difference is over 10 percent and master's evaluation is found highly optimistic. A better evaluation system should be created to get more realistic evaluation from the ship masters.

l. The relation between MET institution and Shipping Companies

It is clear that there is not a good cooperation and coordination between MET institutes and shipping companies which both of them are important for the success of the seat training. So these two organisations are two facets of one thing, in that they should connect and co-operate become competent, and the aim of high quality education and training.

\section{Final Word}

Although there are some problem areas mentioned above the sea training is successful. It is strongly believed that further studies should be made on this issues to improve the quality of training such as better preparation for sea training.

\section{References}

[1] IMO, STCW (2010). Standards Training, Certification and Watchkeeping, IMO, London, UK.

[2] IMO Model Course 7.01, (2012). First Officer and Master,
IMO, London.

[3] IMO Model Course 7.02, (2012). Chief and Second Engineer, IMO, London.

[4] IMO Model Course 7.03, (2012). Officer of the Watch, IMO, London.

[5] IMO Model Course 7.0 4, (2012). Engineering Officer of the Watch, IMO, London.

[6] Wei R., (1999). An Investigation into the Quality Standard Systems (QSS) in Chinese Maritime Institutions- Their Problems, Practicalities of Implementation and recommendations, Master Thesis World Maritime University, Malmoe, Sweden.

[7] Demirel E. And Mehta R. (2009), Developing an Effective Maritime Education and Training System- TUDEV Experiment, IMLA 2009 Conference Proceedings, AccraGhana, 07-10 September 2009.

[8] Demirel E. and Bayer D., (2015). A Study on The Assessment of Sea Training as an Integral Part of Maritime Education and Training, The Online Journal of Quality in Higher Education-July 2016 Volume 3, Issue 3.

[9] Yoon D., Nam T. K., Yim J. B., Ahm Y. S., (2010). Comparison of Training and Education in the Training Ship, International Association of Maritime Universities- AGA11 http://iamu-edu.org/wp-content/uploads/2014/07/Comparisonof-Training-and-Education-in-the-Training-Ship.pdf (Entered: 3 May 2019).

[10] Yoon D. and Ko J. S., (2012). Training Ship's Education System in Asia Countries: Focused on China, Japan and Korea, Abstracts for the Third Maritime Education Summit - Texas A\&M www.tamug.edu/mara/images/abstracts2011.pdf (Entered: 10 May 2019).

[11] IMO, (2019). ISM Code.

[12] EU Seventh Framework Programme (FP7), (2012). Maritime Transport Education \& Competence Development in a Maritime EU, Press 4 Transport, Improving EU Surface Transport Media Visibility https://trimis.ec.europa.eu/sites/default/files/project/document s/20121123_171918_14174_EducationCompetenceDevelopm entMaritimeEU_LLF_FINAL_.pdf (Entered: 13 May 2019).

[13] Weber T. and Nevala A. M, (2006). Employment Trends in all sectors related to the sea or using sea sources, An exhaustive analysis of employment trends in all sectors related to sea or using sea resources, Final report for the European Commission, DG Fisheries and Maritime Affairs C3135/ September 2006, ECOTEC Research \& Consulting.

[14] Shen G., (1999). The impact of the STCW 95 on the on board training programs of shipping companies in China: meeting the challenge of change, World Maritime University Dissertations. http://commons.wmu.se/all_dissertations/429 (Entered: 10 May 2019).

[15] ISF, (2012). On Board Training Record Book for Deck Cadets, MARISEC Publication, London.

[16] WMU (World Maritime University), (2003). Training and Mobility of Seafarers, METNET Thematic Network on Maritime Education, Contract No. 1999-TN. 10983, Project funded by the European Commission under the 5th RTD Framework programme. 